points out some of the considerations that lead to commercial success. A good natural water supply is essential as a supply from the town services can never be counted on. The ideal site should be in the vicinity of a wood and on the northern side of a hill as this makes the formation of ice less expensive. It is also advisable, as at Berne, to combine with the ice rink a bathing establishment for summer use. In Zurich the ice rink is combined with a swimming bath which serves in winter as the water tank for the ice rink. Concrete, iron, copper, cork and bitumen are used in the construction of the freezing plate. As their thermal coefficients of expansion are all different and the temperature fluctuations are large the problem presented difficulties. Owing to the thermal expansion, countless minute cracks appear on the plate and this luckily allows it to 'breathe' without injuring the network of tubes. The production of artificial waves in a bathing pool has been studied for many months in the hydraulic laboratory of Messrs. Escher Wyss. They now produce special plant called the 'undosa' for the economic production of artificial waves. Neuchatel has an open air skating rink, and it appears that it is only lack of capital which prevents other Swiss towns from carrying out similar schemes.

\section{The Science Museum}

IN its annual reports to the Board of Education, the Advisory Council of the Science Museum, while giving a general review of the progress of the Museum as a whole, has usually devoted special consideration to one of the divisions, directing attention to the gaps in its collections and indicating how the collections should be developed. In its report for 1933, the Council has therefore dealt with the important sections Water and Air Transport, and its remarks go to show that unless steps are taken there is likely to be wasteful rivalry between the Science Museum and other museums supported by the State. Some of the aeronautical exhibits, the report says are on loan from the Imperial War Museum and others from the Air Ministry. When the War Museum moves to its new quarters at Bethlem it may wish to withdraw its exhibits, while the Air Ministry is contemplating setting up a museum of its own. "This would inevitably create three exhibitions of aviation, each incomplete, and in competition with one another." The creation of the War Museum has already had an unfortunate effect on the Water Transport Collections, for as a result of its inauguration "practically no models of men-of-war of the period between 1914 and 1920 are available, and consequently the collection in the Science Museum is completely truncated. It is regrettable," the report says, "that in this, as in other cases, national collections of the same subject matter should be split up between different Museums, and thus lose much of their educative value to the public." Another rival of the Science Museum, not referred to in the report, may well be the National Maritime Museum, which must almost inevitably encroach on some of the territory already occupied by the Science Museum.

\section{History of Self-Starters for Motor-Cars}

THE Smithsonian Institution has received from the V. G. Apple Laboratories, Ine., of Dayton, Ohio, a valuable collection of early automotive electrical equipment. The founder of the firm, the late Vincent G. Apple, was one of the pioneers who improved motor-car ignition and lighting systems, and one of the first to produce a successful electric starter. This starter, which was very cumbersome, was listed in 1912 at 350 dollars. To-day, when practically every car has a self-starter, the advertising leaflets are amusing. "Every successful device for the public amusement passes through a period of such enormous popularity that the public overlooks its many imperfected details in the desire to be among the first to possess it." It is pointed out that the necessity of cranking the engine of a motor-car is a most exasperating drawback. Compressed air, gas, acetylene gas and spring starters have all been tried and, except when everything is favourable, they have been found untrustworthy. A starter is a convenience when a car is leaving the garage; it is a necessity when it stops at a busy street corner, but what about starting the car when it stops on a level crossing ? The progress of perfecting these devices during the last few years has been so rapid that there is a danger of the beginning and intermediate steps being forgotten. The Smithsonian, therefore, is gathering a collection, as complete as possible, of lighting, starting and ignition equipment.

\section{The American Institute of Electrical Engineers}

IN commemoration of the fiftieth anniversary of its foundation, on May 13, 1884, the American Institute of Electrical Engineers has issued a very interesting memorial number of Electrical Engineering, representing the official monthly journal and transactions. This number, published in May, and containing more than two hundred pages, is dedicated "To the lasting memory of those public spirited leaders who founded and built to its present eminence the American Institute of Electrical Engineers, and to the inspiration of those of the present and future generations who will continue the constructive leadership of this agency for professional development". Among the famous names of contributors to this issue are those of A. E. Kennelly, who writes on "The Work of the Institute in Standardization", C. A. Adams on "Some Major Events in the Life of the Institute", E. W. Rice, Jr., on "A Century of Progress in 50 Years", M. I. Pupin on "The Equation of Electrical Propagation", while Elihu Thomson and D. C. Jackson deal respectively with "Some High Lights of Electrical History" and "The Evolution of Electrical Engineering".

THEse articles are most useful accounts of progress, and provide an illuminating perspective of the manner in which the electrical engineering industry has attained its present status through the continued effort of the comparatively few, of whom the foregoing names are representative. The biographical notices are no 1ess than 92 in number; England 